\title{
MLADI IN ŽIVLJENJE V OBMEJNIH REGIJAH SLOVENIJE
}

\author{
Karmen Kolenc-Kolnik*
}

Izvleček

UDK 371.8(1-04)

$V$ članku so predstavljeni rezultati raziskave, $v$ kateri je sodelovalo 523 srednješolk in srednješolcev. Preučevano je bilo njihovo mnenje o državni meji in multikulturnosti pestrosti obmejnih regij, njihova prostorska identifikacija in o perspektivah življenja $v$ različnih obmejnih regijah Slovenije.

Ključne besede: srednješolci, državna meja, prostorska identifikacija, obmejne regije.

\section{THE YOUTH AND THE LIFE IN BORDER REGIONS OF SLOVENIA}

\section{Abstract}

This article present the results of research in which we worked with 523 Slovenian secondary school pupils who live in the border regions of Slovenia and Europe. Their opinion on the state border and multicultural diversity of border regions, their spatial identification and perspectives of their lives in different border regions are discussed.

Key words: secondary school pupils, state border, spatial identification, border region.

\footnotetext{
* Dr., docent, Oddelek za geografijo, Pedagoška fakulteta Maribor Univerza v Mariboru, Koroška 160, 2000 Maribor, Slovenija
} 


\section{UVOD}

Vpliv državne meje in stopnja njene odprtosti oziroma zaprtosti dopuščata takšen regionalni razvoj obmejnih območij, ki je rezultat različno kvalitetne povezanosti in soodvisnosti njihovega regionalnega razvoja kot tudi širšega prekomejnega povezovanja. V regionalno povezovanje je že desetletja vključena tudi Slovenija. Povečuje se splošna mednarodna soodvisnost, ki se tudi v Sloveniji krepi, širi. V meddržavnem povezovanju se še posebej velja obračati k sosednjim državam. Poleg te obče usmeritve medregionalnih povezovanj lahko ugotovimo, da je za Slovenijo že od nekdaj zelo pomembno dejstvo tudi njena ozemeljska majhnosti, saj se na vsem njenem državnem ozemlju čutijo neposredni in posredni vplivi sosednjih držav. Tretji pomemben vidik povezanosti Slovenije s sosedstvom pa so narodnostne manjšine.

Predvidevanja in dejanske izkušnje iz drugih evropskih regij nas po mnenju prostorskih sociologov (Mlinar, Klinar) prepričujejo, da bo ob odprtih mejah prišlo do krepitve čezmejnih povezav in s tem do oblikovanja novih ali do obnavljanja nekdanjih regij ali npr. gravitacijskih območij velikih mest, kot sta npr. Trst in Gradec. Tako bo lahko prihajalo do večkratnega neskladja med upravnim (državna meja), etničnim (narodnostne manjšine) in funkcionalnim (velika mesta ). S tem pa se bo vloga naših obmejnih regij ponovno spremenila, še posebej, če upoštevamo njihovo sedanjo različno gospodarsko in družbeno vitalnost.

Pri načrtovanju razvoja obmejnih regij, bi morali poiskati tudi odgovor na vprašanje kako mladi razmišljajo o razvojnih potencialih in perspektivi življenja ob meji, saj so bodoči nosilci njihovega razvoja.

Današnja mladina je tista, ki bo v prihodnosti oblikovala odnose sodelovanja ali pa morda celo stopnjevala nestrpnost med narodi. Išče se odgovor na vprašanje, kaj pomenita $v$ današnji Evropi, mlademu, odraščajočemu človeku njegova prostorska in narodna identiteta, še posebej s v okviru multikulturne pestrosti in specifičnosti življenja ob državni meji. Individualna različnost posameznikovih » gledanj na prostor « je splet njegovih konkretnih zaznav in izkušenj. Njegove sposobnosti razumevanja prostora so zato le delne in subjektivno osnovane.

Med dejavnike, ki vplivajo na mladostnikove predstave, pojmovanje in vrednotenje geografskega prostora, se najpogosteje prištevajo (Downs in Lynn, 1991, Haubrich, 1996, idr.) osebnostne lastnosti in značilnosti posameznika, lastne izkušnje, starši, sorodniki, sošolci in prijatelji kot vpliv primarnih in referenčnih skupin, šola oz. poučevanje kot vir znanja, množična komunikacijska sredstva kot vir informacij ter širša družbena skupnost (narod, državo) kot ustvarjalke družbenega sistema. V njih so povezani čustvenost, vživetost in informiranost, ki v srednješolcu soblikujejo vrednostne lestvice in predznake o tem kaj sprejema in kaj zavrača. Glavni namen raziskave je ugotoviti, v kolikšni meri so omenjene trditve značilne tudi za slovenske srednješolce iz obmejnih regij. 


\section{RAZISKAVA MLADI IN ŽIVLJENJE V OBMEJNIH REGIJAH}

\section{Cilji raziskave, predpostavke in metode dela}

Temeljni cilj raziskave je bil preučiti prostorsko identiteto izbrane slovenske srednješolske populacije in njihovo razumevanje specifičnosti življenja ob državni meji. Opredelili smo dva tematska cilja in predpostavki:

a) Razumevanje in vrednotenje življenja ob državni meji in odnos do same državne meje.

Predpostavka : Večina se bo opredelila do državne meje kot do nepotrebne administrativne formalnosti. Pričakovana pa je večja razlika v mnenjih dijakov glede na to iz katere obmejne regije prihajajo. Večina anketiranih bo soglašala s trditvijo, da je življenje veliko bolj pestro in zanimivo tam, kjer se mešajo kulture, narodi in rase.

b) Občutenje pripadnosti določenemu prostoru .

Predpostavka : Pričakovana je zelo različna opredelitev posameznikov tako do prostorske pripadnosti ( lokalne, regionalne, narodne, mednarodne) kot do življenja drugje. Večja kot bo ponujena prostorska oddaljenost, manjša bo pripravljenost za selitev.

Metodo, ki je bila uporabljena pri raziskavi, uvrščamo med opisne in vzročnoposledično neeksperimentalno empirično pedagoškego raziskovanje, saj z njo poskušamo posneti stanje preučevanega pojava in tudi poiskati zveze med posameznimi parametri. Temelji na anonimnem anketnem vprašalniku za dijake srednjih šol. V celoti je vprašalnik sestavljalo 14 vprašanj. V tem članku so predstavljena štiri izbrana vprašanja. Pri statistični obdelavi podatkov anketnih vprašalnikov so bili izračunani deleži odgovorov in metoda $\chi^{2}$ preizkus vrednosti o statistični pomembnosti razlik. Vsi statistični postopki so povzeti po Sagadinu (1992). Za sestavo vprašalnikov so bili uporabljeni izbrani tipi vprašanj, ki jih uporabljajo $\mathrm{v}$ raziskavah SJM (94/2 in 94/4) zato, ker so se rezultati teh raziskav uporabili za primerjavo in razlago razlik med vzorčnimi skupinami. Časovno je naša raziskava potekala od poletja 1994 do poletja 1998.

\section{Značilnosti populacije}

Anketiranih je bilo 523 dijakov in dijakinj tretjih letnikov izbranih srednjih šol v Sloveniji, starih poprečno 17,1 let . V celotnem vzorcu je bilo 298 deklet $(56,9 \%)$ in 225 fantov (43,1 \%). Slovenske narodnosti je 92,3\% anketiranih, ostalih je 7,7\% ( madžarske 19, italijanske 4, srbske 4, hrvaške 7. Za 6 dijakov ni podatka). Anketirani iz prve, druge, tretje in četrte empirične skupine živijo v obmejnih regijah, anketirani iz pete empirične skupine živijo v osrednji Sloveniji. 
Značilnosti posameznih empiričnih skupin:

- V prvi empirični skupini je bilo zajetih 121 dijakov 3. letnikov gimnazij ( Piran, Koper, G.K.C. Koper, Nova Gorica, Tolmin), ki živijo in se šolajo ob slovenskoitalijanski meji. V skupino je bilo zajeto tudi narodno mešano območje;

- V drugi empirični skupini so bili anketirani 103 dijaki vpisani v tretje letnike gimnazij ob slovensko-madžarski meji (M.Sobota in Lendava). Obe gimnaziji stojita na narodno mešanem območju;

- $\quad$ v tretji empirični skupini je bilo 96 mladih, ki živijo ob slovensko-hrvaški meji in so iz treh različnih gimnazij (Brežice, Kočevje in Ptuj);

- $\quad \mathrm{v}$ četrti empirični skupini je bilo 83 anketirancev z območij ob slovenskoavstrijski meji in prihajajo iz treh srednjih šol ( Gimnaziji Jesenice in Ravne na Koroškem in Srednja gostinska šola Radenci);

- v 5.empirični skupini je bilo 120 dijakov tretjih letnikov iz Celja in Ljubljane (Gimnaziji Lava - Celje in Gimnazija Šentvid - Ljubljana). Skupina predstavlja osrednjo Slovenijo, kjer naj bi bil neposreden vpliv državne meje najmanjši.

\section{Analiza raziskave in ugotovitve}

a) Prva skupina vprašanj je vezana na razumevanje in vrednotenje življenja ob državni meji in odnosa do državne meje. Dijake smo spraševali o osebnih občutenjih, prednostih in slabostih življenja ob državni meji. Na vprašanje o odnosu do državne meje je odgovorilo 509 anketirancev. Izbrali so eno od petih navedenih možnosti. Odgovori na to vprašanje so bili še najbolj enotni. Vprašanje je bilo preizkušeno $\mathrm{z}$ metodo izračuna $\chi^{2}$ vrednosti: $\chi^{2}=24,00>\chi^{2}=23,5(\mathrm{P}=0,10 ; \mathrm{g}=16)$. Preizkus o statistični pomembnosti razlik v osnovni populaciji je pokazal, da če zanemarimo Ho (razlike med stališči posameznih skupin niso statistično pomembne), tvegamo napako, ki je sicer manj kot desetodstotna, vendar več kot petodstotna. Sodimo, da je tolikšno tveganje že preveliko in neutemeljeno, zato ne moremo argumentirati zavrnitev Ho in jo obdržimo. 
Slika št.1 : Odnos do državne meje

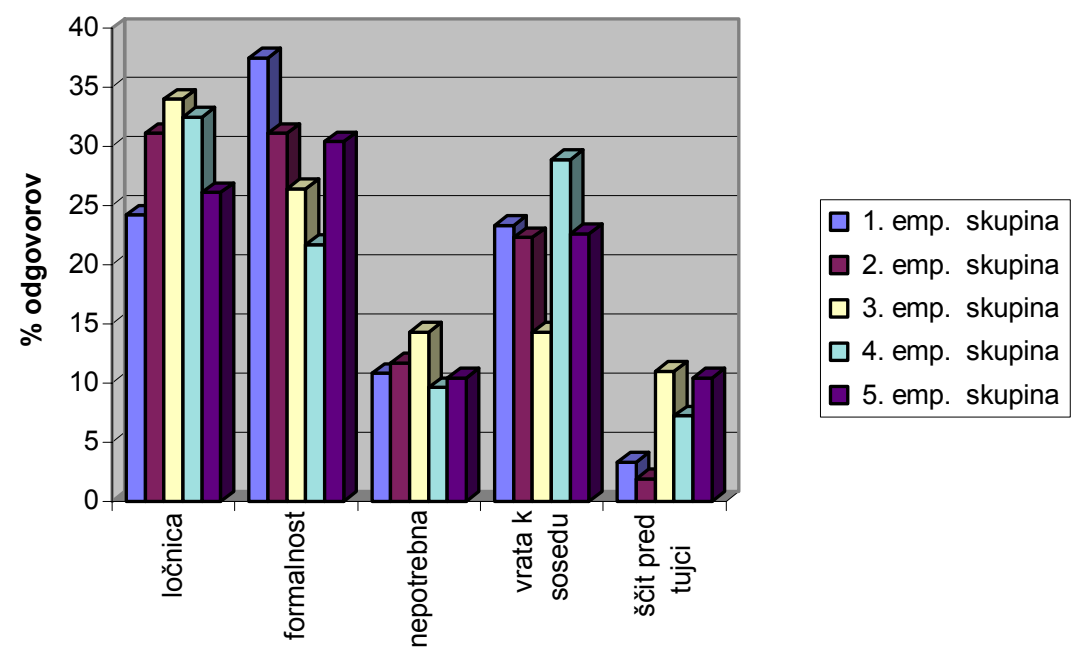

Največjo odprtost do državne meje, ki jo čutijo še najbolj kot formalno oviro, kažejo mladi živeči ob mejah z narodnostnima manjšinama na obeh straneh. Mejo doživljajo kot ločnico, vendar bolj v pozitivnem smislu kot vrata k sosedu in ne kot ščit pred tujci. Najbolj mešane občutke in očitno največ negotovosti pri anketiranih, poraja najmlajša slovensko-hrvaška meja. Srednješolci iz teh obmejnih regij jo izmed vseh najbolj doživljajo kot ločnico in tudi od vseh anketiranih ji v največji meri pripisujejo varovalno nalogo pred tujci. Samo 14,3\% med njimi jih misli, da je državna meja nepotrebna, ker so to vrata $\mathrm{k}$ sosedu. Anketirani iz osrednjega dela Slovenije ne odstopajo pri svojih odgovorih v tem sklopu vprašanj. Državno mejo sprejemajo prej $\mathrm{v}$ pozitivnem, kot $\mathrm{v}$ negativnem pogledu.

Z opredelitvijo stopnje soglašanja, da je življenje veliko bolj pestro in zanimivo tam, kjer se mešajo kulture, narodi in rase, smo ugotavljali v kolikšni meri so mladi naklonjeni multikulturni pestrosti, značilni za večino obmejnih regij. Na vprašanje je odgovorilo 519 anketirancev. 
Slika št. 2 : Stopnja soglašanja o multikulturni pestrosti

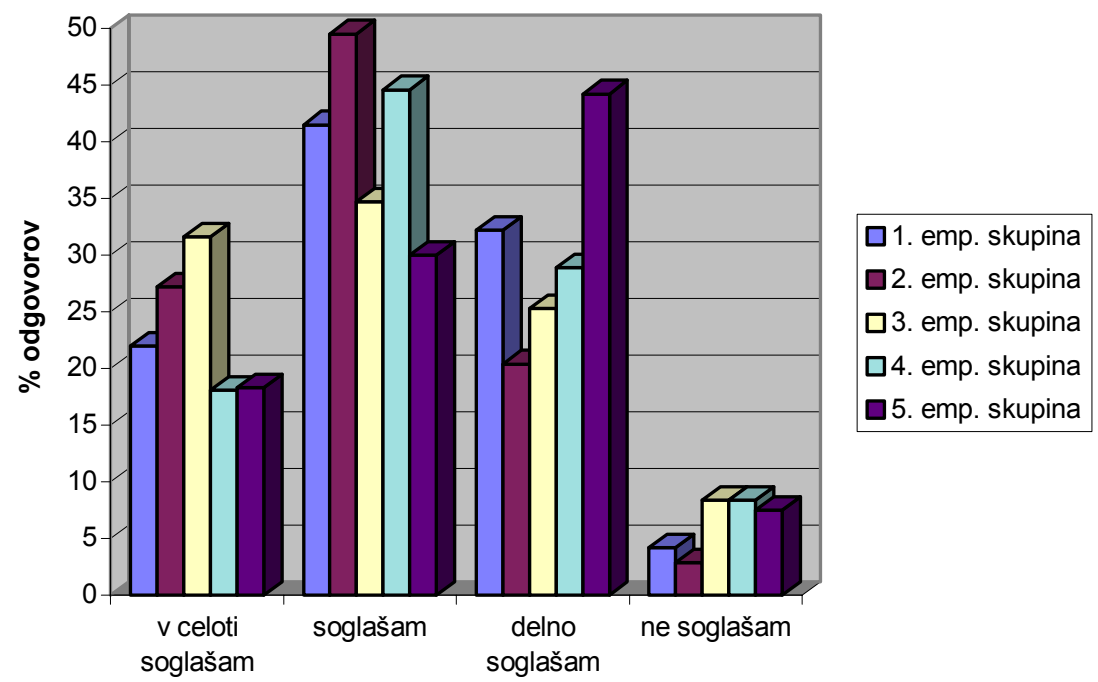

Izračunana vrednost $\chi^{2}=19,4739$ preseže kritično vrednost $\chi^{2}=16,81 \quad(\mathrm{P}=0,01$; $\mathrm{g}=6$ ). Ničelno predpostavko zavrnemo s tveganjem manjšim od $1 \%$. Razlike $\mathrm{v}$ stopnji soglašanja anketiranih skupin so statistično potrjene. Empirični skupini (prva in druga), živeči v obeh narodnostno mešanih območjih, sta izkazali višjo stopnjo strinjanja s postavljeno trditvijo in sta bolj naklonjeni etničnemu pluralizmu. Anketiranci iz Ljubljane in Celja (peta empirična skupina) so mnogo bolj rezervirani do drugih kultur, narodov in ras. S takšnim mnenjem se skupina najbolj približa SJM ( Klinar, 1994, 424 ) kjer : » ... skoraj polovica anketirancev sodi, da mešanje različnih etničnosti prinaša težave « in ne razmišljajo o prednosti.

Delovno predpostavko lahko potrdimo v tistem delu, kjer je pričakovana opredelitev do državne meje kot do nepotrebne administrativne formalnosti. Zavrnjena pa je $\mathrm{v}$ delu, ko se pričakuje večja enotnost in dovzetnost mladih za multikulturno sožitje.

b) Drugi sklop vprašanj je bil vezan na občutek pripadnosti določenemu življenjskemu prostoru in preverjen s stopnjo pripravljenosti na selitev. Na vprašanje je odgovorilo 525 anketiranih. Izhodišče Ho je, da med skupinami anketiranih ni statistično pomembnih razlik. Izračunana vrednost $\chi^{2}=59,76$ močno presega kritično vrednost $\chi^{2}=39,25(\mathrm{P}=0,001 ; \mathrm{g}=8)$, kar pomeni, da lahko ničelno predpostavko $\mathrm{v}$ statistični nepomembnosti razlik med stališči $\mathrm{v}$ posameznih skupinah osnovne 
populacije zavrnemo $\mathrm{s}$ tveganjem manjšim od $0,1 \%$. Razlike med odgovori posameznih skupin so torej statistično pomembne. Kažejo se v vseh petih kategorijah prostorske pripadnosti.

Slika št. 3: Prostorska pripadnost

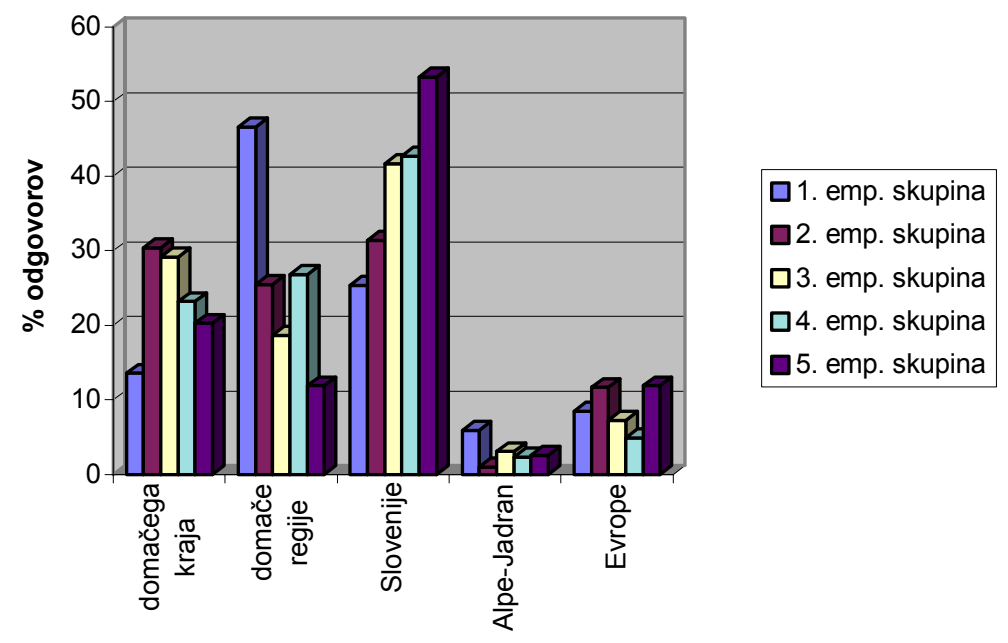

V absolutnem številu se je največ anketiranih opredelilo za Slovenijo (195 ali 37,1\%). Še izrazitejše od skupnega poprečja je opredelitev za državno identiteto navzoča v tretji empirični skupini $(41,7 \%)$, četrti empirični skupini $(42,7 \%)$ in peti empirični skupini $(53,2 \%)$ nekoliko nižja, vendar pa še vedno na prvem mestu pa pri drugi empirični skupini $(31,4 \%)$. Ta skupina je dala tudi skoraj enak delež glasov pripadnosti domačemu kraju oz. vasi (30,4\%).

Mnogo izrazitejša kot na Slovenijo pa je pri dijakih, živečih ob slovensko-italijanski meji, njihova prostorska navezanost na domačo regijo $(46,6 \%)$.

Vse skupine anketiranih so največ enotnosti pokazale v najmanjšem deležu tistih, ki čutijo pripadnost prostoru Alpe - Jadran. Se pa srednješolci v poprečju $(6,4 \%)$ čutijo bolj " evropske " kot anketiranci SJM (1994/ ) z 3,7 \% odgovorov.

Skupina srednješolcev iz osrednjega dela Slovenije (peta empirična skupina) kaže najbolj poenoteno mnenje z mnenjem anketiranih v SJM (1994/2, vprašanje 1.07), kjer se jih je 59,0 \% opredelilo za pripadnost Sloveniji, 23,1 \% za domači kraj, 13,5 $\%$ za regijo itd.. 
Želeli smo tudi ugotoviti stopnjo pripravljenosti srednješolcev na selitev v lokalnem, regionalnem in državnem prostoru ter zunaj matične celine. Odgovori so bili rangirani s petimi stopnjami, od zelo velike pripravljenosti na selitev do zelo velike nepripravljenosti nanjo.

Na prvo vprašanje je odgovorilo 433 anketiranih in na drugo vprašanje 467.

Statistični preizkus Ho predpostavke je pokazal, da se stališča do pripravljenosti za selitev med empiričnimi skupinami pomembno razlikujejo, saj je $\chi^{2}=51,97>\chi^{2}=$ $45,32(\mathrm{P}=\mathrm{o}, \mathrm{oo} 1 ; \mathrm{g}=20)$. Ho zavrnemo in pri tem tvegamo napako, manjšo od $0,1 \%$.

Tabela št. 4: Pripravljenost na selitev

\begin{tabular}{|l|c|c|c|c|c|}
\hline $\begin{array}{l}\text { Zelo pripravljen na } \\
\text { selitev v: }\end{array}$ & $\begin{array}{c}\text { 1.emp. skupina } \\
{[\%]}\end{array}$ & $\begin{array}{c}\text { 2.emp. skupina } \\
{[\%]}\end{array}$ & $\begin{array}{c}\text { 3.emp. skupina } \\
{[\%]}\end{array}$ & $\begin{array}{c}\text { 4.emp. skupina } \\
{[\%]}\end{array}$ & $\begin{array}{c}\text { 5.emp. skupina } \\
{[\%]}\end{array}$ \\
\hline Sosednji kraj & 20.9 & 15.0 & 17.1 & 26.2 & 28.8 \\
\hline $\begin{array}{l}\text { Drugi kraj v isti } \\
\text { regiji }\end{array}$ & 20.9 & 13.4 & 15.9 & 22.5 & 18.6 \\
\hline Druga regija & 9.3 & 19.3 & 30.5 & 13.8 & 7.2 \\
\hline Zunaj Slovenije & 15.1 & 12.5 & 18.3 & 11.9 & 19.6 \\
\hline $\begin{array}{l}\text { Najbližjo sosednjo } \\
\text { državo }\end{array}$ & 8.2 & 5.6 & 6.1 & 10.0 & 1.1 \\
\hline Zunaj Evrope & 25.6 & 35.2 & 12.1 & 16.9 & 24.7 \\
\hline Število odgovorov & 86 & 88 & 82 & 80 & 97 \\
\hline
\end{tabular}

Tudi tu so dijaki potrdili svojo različno pripravljenost na menjavo življenjskega prostora, saj Ho predpostavko, da med različnimi skupinami ni statistično pomembnih razlik, zavračamo in pri tem tvegamo manj kot $0,1 \%$ napako $\left(\chi^{2}=53,66>\chi^{2}=\right.$ 45,32, $\mathrm{P}=0,001 ; \mathrm{g}=20$ ).

Tabela št. 5: Nepripravljenost na selitev

\begin{tabular}{|l|c|c|c|c|c|}
\hline $\begin{array}{l}\text { Zelo ne- pripravljen } \\
\text { na selitev v: }\end{array}$ & $\begin{array}{c}\text { 1.emp. skupina } \\
\%\end{array}$ & $\begin{array}{c}\text { 2.emp. skupina } \\
\%\end{array}$ & $\begin{array}{c}\text { 3.emp. skupina } \\
\%\end{array}$ & $\begin{array}{c}\text { 4.emp. skupina } \\
\%\end{array}$ & $\begin{array}{c}5 . \text { emp. skupina } \\
\%\end{array}$ \\
\hline sosednji kraj & 20.9 & 20.2 & 16.8 & 14.8 & 10.3 \\
\hline $\begin{array}{l}\text { drugi kraj v isti } \\
\text { regiji }\end{array}$ & 15.2 & 15.9 & 13.3 & 9.9 & 11.2 \\
\hline druga regija & 6.9 & 14.9 & 11.1 & 20.9 & 14.7 \\
\hline izven Slovenije & 10.5 & 14.9 & 13.3 & 18.5 & 20.7 \\
\hline $\begin{array}{l}\text { najbližjo sosednjo } \\
\text { državo }\end{array}$ & 2.3 & 15.9 & 23.3 & 12.3 & 25.9 \\
\hline $\begin{array}{l}\text { izven Evrope } \\
\text { število odgovorov }\end{array}$ & 44.2 & 18.2 & 22.2 & 23.6 & 17.2 \\
\hline
\end{tabular}


Večina anketirancev je navezana na Slovenijo in jo izbira kot državo želenega bivanja. Prav tako je večina anketirancev navezana na domačo regijo. Ugotovimo lahko, da je pripravljenost na selitev zunaj Evrope precej večja (pop. 22,9 \%), kot pripravljenost na selitev v najbližjo sosednjo državo (pop. 6,2 \% ).

Zanimive so velike razlike med anketiranimi skupinami. Več podobnosti v mišljenju so pokazali srednješolci iz prve in pete empirične. skupine. Najbolj se to kaže pri pripravljenosti za selitev zunaj Slovenije, izrazito pa so nenaklonjeni selitvi znotraj države. Odgovori druge empirične skupine kažejo najnižji delež ( 29,1 \% ) tistih, ki niso pripravljeni na selitve, hkrati pa najvišji delež tistih, ki so nanje pripravljeni ( $42,7 \%$ ). Največji delež odklonilnih odgovorov za selitev v sosednjo državo so pokazali mladi iz Brežic, Kočevja in Ptuja (tretja empirična skupina). Anketiranci, živeči ob slovensko-avstrijski meji, pa so največjo naklonjenost namenili selitvam $\mathrm{V}$ najožjem, krajevnem prostoru. So edina skupina za katero je prostorske oddaljenosti pomembna pri odločitvi.

V začetku postavljeno predpostavko lahko samo delno potrdimo, saj se je pokazala le pričakovana različna opredelitev posameznikov, tako do prostorske pripadnosti kot $\mathrm{z}$ vidika želje živeti drugje. Ne moremo pa je potrditi v predvidevanju, da večja kot bo ponujena prostorska oddaljenost, manjša bo pripravljenost za selitev. Element prostorske oddaljenosti pri anketirancih ni bil prevladujoč. Bolj kot to je bilo pomembno, iz katere regije prihajajo anketiranci.

\section{SKLEP}

Rezultati ankete so prikazani na majhni in izbrani populaciji srednješolcev, vendar so pomembni, ker prikazujejo odnos bodočih intelektualcev in nosilcev družbenega razvoja do njihove domače regije. Da je stopnja gospodarske razvitosti in meddržavnih povezav obmejnih regij zelo pomembna za kakovost življenja ljudi $\mathrm{v}$ njih, vemo že dolgo. To nam potrjujejo odgovori srednješolcev, ki živijo ob slovensko-italijanski meji, in $\mathrm{v}$ veliki meri tudi mladi iz slovensko-avstrijskih obmejnih regij. Ugotovljena nizka stopnja vrednotenja in navezanosti na domači obmejni prostor pri mladih iz slovensko-madžarskih in slovensko-hrvaških obmejnih regij, postavlja pomembno vprašanje: Kdo bo v bodoče poseljeval in razvijal obmejne regije, če ne domačini?

Statistično potrjene razlike $\mathrm{v}$ mnenjih mladih govorijo o dejanski navzočnosti različnih vrednotenj domače regije. Kljub potrjeni prostorski identiteti in pozitivnem odnosu do multikulturne pestrosti obmejnih regij narodnostno mešanega ozemlja, mladi živeči ob slovensko- madžarski meji ne vidijo svoje prihodnosti v njej. Njihovi vrstniki iz narodnostno mešanega ozemlja ob slovensko-italijanski meji so veliko bolj zadovoljni $\mathrm{v}$ svoji domači regiji, vendar so tudi naklonjeni selitvam. Najbolj 
konservativni v svojih pogledih in zadovoljni z obstoječim življenjskim prostorom so mladi, živeči v osrednjem delu Slovenije.

Celovit pogled na obmejni prostor in vrednotenje narodne identitete in mednarodnega sodelovanja je pomembna naloga regionalnih raziskav. Omogočajo nam lahko tudi vpogled v njihovo bodočo poselitveno dinamiko in oceno razvojnih možnosti. Zato pa je tudi potrebno bolje poznati in upoštevati poglede mladih. Njihove osebne predstave o nekem konkretnem prostoru, v našem primeru obmejne regije, se ne ujemajo vedno tako $\mathrm{z}$ mnenjem starejših (SJM), kot sedanjim interpretacijam t.i. družbene realnosti ali pa geografskemu pojmovanju tega prostora.

\section{LITERATURA IN VIRI}

1. Center za raziskovanje javnega mnenja in množičnih komunikacij, 1994: Slovensko javno mnenje in mednarodna raziskava narodne identitete. Pregled in primerjava rezultatov. Univerza v Ljubljani, Fakulteta za družbene vede-Inštitut za družbene vede, Ljubljana.

2. Downs R.M., Lynn S.L., 1991: The Developement of Expertise of Geography: A Cognitive Developement Approach to Geographic Education. Annals Of American Geographers, Vol.84, No.2, 175-188.

3. Haubrich H., 1994: Territorial Identiti and Territorial Order in Europe. Europe and the World in Geographocal Education. Papers of the IGU, Geographiedidaktische Forschungen, Band 25, 35-53, Freiburg.

4. Klinar P., 1994: O nacionalni identiteti in etnonacionalizmih. Slovenija V prehodnem obdobju. Teorija in praksa, št.5/6, 424, Ljubljana.

5. Kolenc-Kolnik K., 1997: Mednarodno razumevanje in sodelovanje v luči geografske vzgoje in izobrazbe: na primeru slovensko-italijanskega in slovenskomadžarskega obmejnega prostora. Doktorska disertacija, Filozofska fakulteta, Ljubljana.

6. Kolenc-Kolnik K., 1994: Pouk geografije v srednji šoli z vidika poznavanja in razumevanja sosednjih držav; na primeru slovensko-hrvaškega obmejnega območja. Znanstvena revija št.1, letnik 6, 55-64, Maribor.

7. Mlinar Z., 1994: Trendi in problemi družbenoprostorskih sprememb. Teorija in praksa, letnik 31, Št. 11/12, 956-967, Ljubljana.

8. Sagadin J., 1992: Osnove statističnih metod za pedagoge. Ljubljana. 


\title{
THE YOUTH AND THE LIFE IN BORDER REGIONS OF SLOVENIA
}

\begin{abstract}
Summary
In the article there is a presentation of results of a research in which we worked with 523 Slovenian secondary school pupils who live in the border regions of Slovenia and Europe. Their opinion on state border and multicultural diversity of border regions, their spatial identification and perspectives of their lives in different border regions have been researched. Influence of the state border and level of its openness or constipation allow such regional development of border regions. They are a result of a different qualitative connection and interdependence of their regional development and over-border connections on all levels of life. Slovenia has been a part of regional connecting for decades. Common international interdependence is growing. Beside the common trend of interregional connections, we can also find out that for Slovenia its small territory has always been a very important fact, because we can feel the direct and mediate influences of neighbouring countries throughout the whole country. In Slovenia it is strengthening and extending, for that it is especially important to turn toward neighbouring countries. The third, but not last, aspect of Slovenian connections with neighbouring countries are the national minorities. The results of our survey are shown on a small and chosen population of secondary school pupils. However they are important because they show attitudes of future intellectuals and bearers of social development of their domestic region. We have known for a long time that the level of economic development and international connections of border regions is very important for the quality of life in them. This has been confirmed by the answers given by the pupils who live at Slovenian-Italian border and has mostly been confirmed also by the pupils from Slovenian-Austrian border regions. Relatively low level of valuation and attachment to domestic border region that has been demonstrated for example by the youth from Slovenian-Hungarian and Slovenian-Croatian border regions and the fact that they are very willing to emigrate from their home region, make us think about who will inhabit and develop border regions in the future, if the natives are not going to.
\end{abstract}

